\title{
MANAJEMEN SEKOLAH ISLAM TERPADU \\ DALAM PEMBENTUKAN KARAKTER BANGSA \\ YANG PANCASILAIS DI SDIT MUHAMMADIYAH \\ GUNUNG TERANG DAN SDIT PERMATA BUNDA III SUKABUMI BANDAR LAMPUNG
}

\author{
Riyuzen Praja Tuala \\ Uiniversitas Islam Negeri Raden Intan Lampung \\ Jl. Letkol H. Endro Suratmin, Kota Bandar Lampung, Lampung 35131 \\ E-mail: riyuzen.tuala@gmail.com
}

\begin{tabular}{c|c|c}
\hline Received: & Revised: & Approved: \\
26/10/2018 & $29 / 11 / 2018$ & $29 / 11 / 2018$ \\
\hline
\end{tabular}

DOI: http:/ / dx.doi.org/10.32332/akademika.v23i2.1242

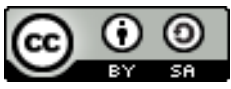

Manajemen Sekolah Islam Terpadu Dalam Pembentukan Karakter Bangsa yang Pancasilais di SDIT Muhammadiyah Gunung Terang dan SDIT Permata Bunda III Sukabumi Bandar Lampung Licensed Under a Creative Commons Attribution-ShareAlike 4.0 International License

\begin{abstract}
This study aimed to determine the development of quality management-based teaching staff at SDIT Muhammadiyah Gunung Terang and SDIT Permata Bunda III Sukabumi Bandar Lampung. The focus of the problem in this study was on the management aspects of teacher quality coaching. This study used a qualitative approach with a case study design. The data was collected through interviews with principals, foundation managers, and teachers. The data was also collected by examining and collecting relevant documents, and making direct observations in both schools. The validity of the data included credibility, transferability, dependability, and confirmation.
\end{abstract}


The data were analyzed by data analysis techniques including data reduction, data display, verification, and conclusion. The results of the study showed that the two schools had implemented a modern teacher development pattern through the implementation of threestep management, namely planning, implementation and evaluation. The orientation of teacher development is directed at two main things, the achievement of high academic competencies (pedagogic, social, personal and professional), spiritual competencies that are "uswatun hasanah" and istiqomah based on Islamic teachings: Al-Qur'an and AlHadist and students' character become the generation who implement Pancasila.

Keywords: Management, Integrated Islamic school, and Pancasila.

\begin{abstract}
Abstrak
Penelitian ini bertujuan untuk mengetahui pembinaan mutu tenaga pendidik berbasis manajemen di SDIT Muhammadiyah Gunung Terang dan SDIT Permata Bunda III Sukabumi Bandar Lampung. Fokus masalah dalam penelitian ini adalah pada aspek manajemen pembinaan mutu guru.Penelitian ini menggunakan pendekatan kualitatif dengan rancangan studi kasus. Data dikumpulkan melalui wawancara dengan kepala sekolah, pengurus yayasan dan guru. Data juga dikumpulkan dengan memeriksa dan mengumpulkan dokumen yang relevan dan melakukan observasi langsung di kedua sekolah. Untuk menguji keabsahan data digunakanuji credibility, transferability, dependability, dan confirmability. Data yang terkumpul dianalisis dengan teknik analisis data meliputi : reduksi data (data reduction), penyajian data, verifikasi data / penarikan kesimpulan. Hasil penelitian menunjukkan kedua sekolah sama-sama telah menerapkan pola pembinaan guru yang moderen melalui implementasi tiga langkah manajemen yaitu perencanaan, pelaksanaan dan evaluasi. Orientasi pembinaan guru diarahkan pada dua hal utama yaitu pencapaian kompetensi akademik yang tinggi (pedagogik, sosial, kepribadian dan profesional), kompetensi spiritual yang uswatun hasanah dan istiqomah berlandaskan ajaran Islam: Al-Qur'an dan Al-Hadist dan karakter anak didik menjadi penerus bangsa yang pancasilais.
\end{abstract}

Kata Kunci: Manajemen, Sekolah Islam Terpadu, dan Pancasila.

\title{
A. Pendahuluan
}

Pada kurun waktu sepuluh tahun terakhir ini terjadi beberapa perubahan penting dan menarik dalam dunia pendidikan Indonesia. 
Hal ini ditandai dengan lahirnya beberapa model pendidikan baru yang digagas oleh pemerintah melalui Kementerian pendidikan dan Kebudayaan seperti Rencana Sekolah Berstandar Internasional (RSBI), Sekolah Berstandar Nasional ( SBI), Rencana sekolah Standar nasional (RSSN), dan Sekolah Standar Nasional ( SSN ). Bahkan lahir pula Boarding School dan Sekolah Islam terpadu.

Perubahan trend pendidikan ini menarik untuk dicermati lantaran selama ini pemerintah memang masih terus mencari formula pendidikan yang pas yang mampu menjawab kebutuhan masyarakat masa kini dan masa yang akan datang. Terakhir digulirkannya kurikulum K13 revisi. Disisi lain, ada semacam ketidak puasan sekaligus semangat baru yang mulai tumbuh subur dimasyarakat yang menginginkan putera-puterinya belajar di sekolah yang mereka sebut sebagai "sekolah masa depan". Yaitu sekolah yang mampu membekali putera puteri mereka tidak saja dengan ilmu pengetahuan umum dan keterampilan umum tetapi juga dengan bekal ilmu keagamaan yang cukup memadai.Nampaknya eksistensi Madrasah belum dianggap cukup untuk memberi "sangu" kehidupan masa depan yang sangat kompleks. Maka model boarding school dan Sekolah Islam Terpadu dipandang sebagai alternatif untuk memenuhi harapan tersebut. Di Indonesia saat ini telah berdiri suatu organisasi yang mewadahi (semacam forum komunikasi) sekolah-sekolah islam terpadu yang diberi nama Jaringan Sekolah Islam terpadu (JSIT).

Kehadiran Sekolah IslamTerpadu (SIT) sebagai suatu inovasi baru dalam sistem pendidikan nasional menjadi menarik dan penting untuk dipelajari karena pertumbuhan jumlah sekolah, jumlah siswanya, bahkan prestasinya yang mampu bersaing dengan sekolah-sekolah pemerintah. SIT terdiri dari dua model. Pertama, SIT yang tergabung dalam JSIT dan yang kedua sekolah-sekolah swasta yang dikelola masyarakat atau organisasi berbasiskan keagamaan yang memodifikasi kurikulumnya menjadi kurikulum yang serupa dengan SIT seperti Sekolah Dasar Muhammadiyah, Gunung Terang,Tanjung Karang Barat, Bandar Lampung.

Fenomena munculnya semangat baru bahkan kepercayaan dan harapan baru masyarakat pada SIT tersebut tentu bukan tanpa alasan. 
Sahroni ${ }^{1}$ mengemukakan empat alasan mengapa ia menyekolahkan anaknya di SIT sebagai berikut: Pertama, pendidikan harus mampu membekali anak untuk hidup di dunia maupun di akherat. Di SIT selain aspek akademik yang dikembangkan juga pendidikan agama Islam dengan porsi yang lebih banyak. Kedua, Menyediakan program pengembangan karakter, soft skill. Berupa program pembentukan karakter yang dilaksanakan tiap pekan, program pendidikan sosial dan kegiatan kepramukaan yang memiliki basis hingga tingkat internasional ( wawasan global).Ketiga, biaya sekolah yang tinggi berbanding lurus dengan kuantitas dan kualitas kegiatan seperti kegiatan Tahfizul Qur'an. Keempat, manajemen pembinaan guru yang relatif berbeda dengan sekolah lain. Pembinaan secara berkesinambungan dilakukan bukan saja pada empat kompetensi umum ( Kepribadian, sosial, paedagogik dan profesional), melainkan juga ditambah dengan satu kompetensi khusus yakni kompetensi spiritual. ArySaputra ${ }^{2}$ dalam penelitiannya menemukan empat alasan sekaligus harapan orang tua menyekolahkan anaknya di SIT sebagai berikut: 1. Anak memilki Pondasi Agama, 2. Anakmenjadi Hafiz Al-Qur'an, 3. Anak memiliki Kecerdasan dan Intelektual, 4. Anak terjamin keamanannya di Sekolah.

Berdasarkan kedua pendapat tersebut, nampak jelas latar belakang orang tua mempercayakan SIT sebagai lembaga pendidikan tempat anaknya belajar dan menuntut ilmu. Jika disederhanakan maka terdapat dua alasan ;Pertama, kurikulum dan proses pembelajaran SIT memiliki muatan lebih dibanding sekolah lainnya. Muatan tersebut adalah muatan spiritual keagamaan. Kedua, manajemen pembinaan guru dianggap lebih baik dan dianggap memiliki dampak yang luar biasa terhadap prestasi akademik dan non akademik siswa. Ketiga, akreditasi sekolah menjadi daya tarik dan kepercayaan tersendiri bagi masyarakat dalam menentukan pilihan sekolah untuk anak-anaknya.

Beberapa argumen empiris tersebut menumbuhkan keinginan peneliti untuk melakukan suatu kajianilmiah berupa penelitian

\footnotetext{
1 https://www.kompasiana.com/sahroni7221/563c5206c723bd83073d6e61/ mengapa-saya-memilih-sekolah-islam-terpadu, diakses pada Kamis, 18 Oktober Pk. 11.00 WIB.

${ }^{2}$ YoskarKadarismandanArySaputra, "Motivasi Orang TuaMenyekolahkanAnakkeSekolah Islam Terpadu (StudipadaSdit-al-madinah Kota Pekanbaru)," Jurnal Online MahasiswaFakultasIlmuSosialdanIlmuPolitikUniversitas Riau 2, no. 2 (2015).h. 14.
} 
khususnya tentang manajemen pembinaan guru di SIT. Dalam penelitian ini SDIT Muhammadiyah Gunung terang Bandar Lampung dan SDIT Permata Bunda III Sukabumi Bandar lampung peneliti tetapkan sebagai obyek penelitian. Dipilihnya kedua SDIT tersebut karena kedua sekolah merupakan sekolah yang berprestasi. SDIT Permata Bunda III adalah pemekaran dari SDIT PB I dan SDIT PB II. SDIT PB I merupakan pelopor SIT di Bandar Lampung. Sekolah ini meski usianya relatif masih muda telah menunjukkan prestasi yang membanggakan antara lain pada tahun 2018 berhasil meraih Juara I lomba mengajar Bahasa Indonesia tingkat Propinsi Lampung dan Sumatera, Juara I Putera cabang panahan O2SN Tingkat Propinsi. Sedangkan SDIT Muhammadiyah Gunung terang Bandar Lampung adalah SDIT berprestasi pertama di Lingkungan Perguruan Muhammadiyah jenjang Sekolah Dasar di Bandar Lampung bahkan di Propinsi Lampung. Banyak prestasi yang dicapai SDIT Muhammadiyah ini. Antara lain pada tahun 2017 meraih medali emas lomba Tahfidz OlympicAD tingkat nasional, medali emas Musabaqoh Fahmil Qur'an OlympicAD Tingkat Nasional. Pada tahun 2018 menjadi Pemakalah Seminar Nasional Guru berprestasi Pendidikan Dasar dan Menengah Kemdikbud serta Finalis dalam Grandong lomba buku bacaan sekolah dasar Kemdikbud.

Sebelumnya, terdapat beberapa penelitian terdahulu yaitu , Pertama, Paradigma Kritis Pancasila dalam Dimensi Pendidikan Islam oleh Arif Rahman ${ }^{3}$ dengan hasil kajian menunjukkan bahwa posisi pancasila seharusnya memang mendapat ruang yang berarti, di satu sisi karena prinsip-prinsip Pancasila terilhami dari Islam, disisi lain Islam memberikan legitimasi yang kuat bagi terlaksananya prinsip Pancasila yang sejalan dengan landasan Islam.Kedua, manajemen pendidikan pesantren modern dalam pembentukan karakter anak: Studi Kasus Pada Pondok Pesantren Modern Diniyyah Pasia Kabupaten Agam oleh Deded Sulaiman ${ }^{4}$ Dari penelitian yang dilakukan disimpulkan bahwa pimpinan manajemen di Pondok Pesantren Modern Diniyyah Pasia adalah kepemimpinan demokrastis yang ditandai dengan adanya konsensus

${ }^{3}$ Arif Rahman, "Paradigma Kritis Pancasila dalam Dimensi Pendidikan Islam" 10, no. 1 (2015): 20.

4 Deded Sulaiman, "MANAJEMEN PENDIDIKAN PESANTREN MODERN DALAM PEMBENTUKAN KARAKTER ANAK:," t.t., 8. 
kesepakatan dalam menentukan perencanaan, pengorganisasian dan pengontrolan. Kata Kunci: Manajemen pendidikan, pembentukan karakter. Ketiga, manajemen guru raudlatul athfal (ra) dalam total quality management (tqm) oleh Fu'ad Arif Noor ${ }^{5}$ Dalam TQM (Total Quality Management), penulis berusaha menukilkan pemikiran untuk mencari alternatif Manajemen Guru Raudlatul Athfal (RA) dalam Total manajemen guru Raudlatul Athfal (RA) yang efektif mulai dari sistem rekrutmen dan penempatan, indusksi dan jaminan kesejahteraan, serta pengembangan keprofesionalan guru. Manajemen guru yang efektif dimulai sejak perekrutan, penempatan, induksi guru baru, kesejahteraan yang baik, dan pengembangan keprofesionalan berkelanjutan.

Berdasarkan latarbelakang dan hasil peninjauan penelitian terdahulu, maka rumusan masalah yang akan dianalisis dalam penelitian ini adalah :Bagaimanakah Manajemen Sekolah Islam Terpadu (Studi Kasus di SDIT Muhammadiyah Gunung terang dan SDIT Permata Bunda III Sukabumi Bandar lampung). Penelitian ini bertujuan untuk mendeskripsikantentang manajemen pembinaan tenaga pendidik (guru) yang ada dikedua SDIT. Pembahasan akan menyasar pada implementasi tiga fungsi manajemen yaitu fungsi perencanaan, fungsi pelaksanaan dan fungsi pengawasan (evaluasi) di kedua sekolah.Hal tersebut didasarkan pada argumen bahwa keberhasilan kedua SDIT dalam meraih banyak prestasi termasuk kecintaan dan kepercayaan masyarakat tentu tidak terlepas dari prestasi manajerial kepala sekolah bersama dewan guru. Hasil penelitian ini diharapkan dapat memperkaya teori-teori dan diskursus tentang manajemen pembinaan mutu guru disatu sisi dan disisi lain dapat memberi manfaat yang sebesar-besarnya bagi sekolah dan masyarakat dalam mengelola proses pembelajaran yang berkualitas.

\section{B. Metode Penelitian}

Jenis penelitian ini adalah penelitian kualitatif deskriptif, yaitu data yang dikumpulkan berbentuk kata-kata, gambar, bukanangkaangka ${ }^{6}$.Bogdan dan Taylor, seperti yang dikutip oleh LJ.Moleong,

${ }^{5}$ Fu'ad Arif Noor, "MANAJEMEN GURU RAUDLATUL ATHFAL (RA) DALAM TOTAL QUALITY MANAGEMENT (TQM)," Jurnal Pendidikan Islam 3, no. 1 (2015): 21.

${ }^{6}$ Danim Sudarman, Menjadi Peneliti Kualitatif Rancangan Metodologi, Presentasi, dan Publikasi Hasil Penelitian untuk Mahasiswa dan Penelitian Pemula Bidang Ilmu Sosial, Pendidikan, dan Humaniora (Bandung: Remaja Rosdakarya, 2002). h. 51. 
menyatakan bahwa penelitian kualitatif adalah prosedur penelitian yang menghasilkan data deskriptif berupa kata-kata tertulis atau lisan dari orang-orang dan perilaku yang diamati ${ }^{7}$.

Menurut Moleong8, terdapat sebelas karakteristikpenelitian kulitatif yang harus dipenuhi yaitu:1. Latar alamiah, 2. Manusia sebagai alat, 3. Metode kualitatif, 4. Analisis data secara induktif, 5. Teori dari dasar (grounded theory), 6. Deskriptif, 7. Lebih mementingkan proses dari pada hasil, 8. Adanya batas yang ditentukan oleh focus, 9. Adanya kriteria khusus untuk keabsahan data, 10. Desain yang bersifat sementara, 11. Hasil penelitian disepakati dan dirundingkan bersama.Berdasarkan karakteristik tersebut, makadengan menggunakan metode kualitatif, penelitian ini dimaksudkan untuk mendapatkan informasi yang akurat tentang manajemen yang diterapkan di kedua SDIT tersebut.

Penelitian ini menggunakan paradigma interpretif dengan pendekatan fenomenologis-naturalistik. Paradigma ini bertujuan menjelaskan dunia sosial dari kaca mata aktor yang terlibat di dalamnya. Menurut Cresswell seperti yang dikutif Sugiono9 ${ }^{9}$, pada pendekatan fenomenologis peneliti melakukan pengumpulan data dengan observasi partisipan untuk mengetahui fenomena essensial partisipan dalam pengalaman hidupnya. Rancangan penelitian menggunakan studi kasus, karena menurut Yin $^{10}$ studi kasus adalah sebuah penyelidikan empiris yang menginvestigasi fenomena kontemporer dalam konteks kehidupan nyata, khususnya ketika batasan antara fenomena dan konteks tidak begitu jelas. Melaui studi kasus ini akan diperoleh gambaran tentang langkah-langkah manajemen pembinaan tenaga pendidik (guru) yang dilakukan oleh kepala sekolah di kedua SDIT tersebut.

Dengan mengacu pendapat Miles dan Huberman ${ }^{11}$, yang menyatakan bahwa sumber data dalam penelitian kualitatif adalah manusia dan bukan manusia.Dalam penelitian kualitatif data yang

${ }^{7}$ Lexy J Moleong, Metodologi Penelitian Kualitatif (Bandung: PT Remaja Rosdakarya, 2000). h. 3.

${ }^{8}$ Lexy J Moleong, Metodologi Penelitian Kualitatif (Bandung: RemajaRosdakarya, 2008).h. 257.

${ }^{9}$ Sugiyono, Metode Penelitian Kombinasi (Bandung: Alfa Beta, 2012). h. 14

${ }^{10} \mathrm{~K}$ Yin Robert, Studikasus (Desaindan Metode) (Jakarta: Raja GrafindoPersada, 2011). h. 1.

${ }^{11}$ Matthew B. dan A. Michael Huberman Miles, Analisis Data Kualitatif (Jakarta: UI -Press, 1992). h. 15. 
dimunculkan berwujud kata-kata dan bukan rangkaian angka. Data itu mungkin telah dikumpulkan dalam aneka macam cara (observasi, wawancara, intisari, dokumen,pita rekaman) dan yang biasanya diproses melalui pencatatan, pengetikan, penyuntingan, atau alat tulis. Maka dalam penelitian ini sumber data utamanya adalah Kepala Sekolah,Tim Penjaminan Mutu Sekolah dan beberapa guru dari kedua SDIT.Sedangkan sumber data non manusia diambil dari dokumenbaik dalam bentuk tulisan maupun gambar.

Teknik pengumpulan data dalam penelitian ini meliputi Wawancara mendalam(indepht interview ) dengan informan, observasi dilingkungan sekolah dan mengumpulkan dokumen-dokumen yang diperlukan (dokumentasi). Teknik tersebut mengacu pada pendapat Sugiyono ${ }^{12}$, yang menyatakan bahwa teknik pengumpulan data pada penelitian kualitatif terdiri atas teknikwawancara, teknikpengamatan/0bservasi, dan teknik dokumentasi.Untuk membuktikan apakah penelitian yang dilakukan benar-benar merupakan penelitian ilmiah sekaligus untuk menguji data yang diperoleh maka perlu dilakukan uji keabsahan data. Menurut Sugiyono ${ }^{13}$. Uji keabsahan data dalam penelitian kualitatif meliputi uji credibility, transferability, dependability, dan confirmability. Dalam penelitian ini untuk menguji keabsahan data digunakan ujicredibility derajat kepercayaan), transferability (keteralihan), dependability (kebergantungan), danconfirmability ( kepastian). Teknik analisis data dalam penelitian ini meliputi reduksi data (data reduction), penyajian data( display), verifikasidata/penarikan kesimpulan (conclusionsdrowing/ verifiying).

Dalam penelitian ini tahapan yang telah peneliti lalui meliputi tahappralapangan, tahappekerjaanlapangan, tahapanalisis data, tahapevaluasidanpelaporan. Tahapan ini didasarkan pada pendapat Moleong $^{14}$, yang menyatakan ada empat tahapan dalam pelaksanaan penelitian kualitatif yaitu tahap pra lapangan, tahap pekerjaan lapangan, tahap analisis data, tahap evaluasi dan pelaporan.

${ }^{12}$ Sugiyono, Metode Penelitian Kuantitatif, Kualitatif Dan RED (Bandung: CV. Alfabeta, 2013), h. 145, 231, 240 .

${ }^{13}$ Ibid, h. 270

${ }^{14}$ Moleong, Op. Cit. h. 127-148. 


\section{Perencanaan Pembinaan Tenaga Pendidik (Guru) SDIT Muhammadiyah Gunung Terang dan SDIT Permata Bunda III Sukabumi}

Langkah manajerial pertama yang diaanggap sangat penting dan strategis dalam menyiapkan SDM guru yang berkualitas disekolah ini dimulai dengan membuat perencanaan.Langkah perencanaan pertama diawali dengan melakukan rekrutmen berupa penerimaan, seleksi dan penempatan) calon guru yang dilakukan oleh panitia seleksi yang terdiri atas unsur Pimpinan Cabang Muhammadiyah (PCM) dan Tim Penjaminan Mutu Sekolah yang beranggotakan Kepala Sekolah dan para Wakil Kepala Sekolah.Seleksi terdiri atas seleksi berkas, tes kemampuan dasar, tes mengajar (micro teaching), dan wawancara. Pada tahap seleksi berkas terdapat sejumlah kriteria yang harus dipenuhi apabila pelamar hendak dinyatakan lolos seleksi. Kriteria tersebut meliputi : pendidikan minimal S1 ( alumni keguruan ), IPK minimal 3,0, Hafal Al-Qur'an untuk guru mata pelajaran umum minimal 1 juz dan untuk guru agama minimal 4 juz, tidak merokok, tidak melakukan pacaran, usia maksimal 30 tahun. Tes kemampuan dasar meliputi penguasaan keilmuan umum (bidang studi), wawasan keagamaan dan wawasan kependidikan.Tes ini akan dijadikan salah satu pertimbangan utama dalam menempatkan yang bersangkutan mengajar di kelas tertentu.Tes mengajar (micro teaching) dimaksudkan untuk mengetahui seberapa baik kemampuan calon guru dalam membuat persiapan mengajar (RPP dan bahan ajar) dan mengimplementasikannya dalam kegiatan pembelajaran sesuai dengan standar waktu dan target capaian. Pada tahap ini calon guru akan dilihat kemampuannya dalam penguasaan materi dan penguasaan kelas. Tahap akhir adalah tes wawancara. Wawancara dimaksudkan untuk mengeksplorasi lima hal ; pertama, standar kompetensi, kedua, wawasan kependidikan, ketiga, wawasan keagamaan dan kemuhammadiyahan, keempat, potensi dan motivasi bekerja dan kelima, potensi pengembangan diri.

Langkah perencanaan yang kedua adalah menyiapkan program peningkatan kompetensi guru setelah calon guru tersebut diterima sebagai guru tetap. Calon guru yang lolos seleksi ditetapkan sebagai guru dalam masa percobaan selama 6 bulan. Program tersebut meliputi pembinaan empat kompetensi guru yaitu kompetensi paedagogik, kompetensi kepribadian, kompetensi sosial dan kompetensi profesional. Pembinaan 
kompetensi guru memerlukan instrumen dan metode yang tepat untuk masing-masing kompetensi. Pembinaan kompetensi paedagogik guru akan dilaksanakan melalui interaksi akademik dalam proses pembelajaran sehari-hari. Indikator keberhasilan capaian kompetensi ini dapat diukur melalui peningkatan hasil belajar peserta didik (akademik dan non akademik/kurikuler dan ekstrakurikuler) sebagai dampak langsung dari kemampuan guru dalam mengawal dan mengelola pembelajaran. Pembinaan kompetensi kepribadian dan kompetensi sosial akan dilakukan secara simultan dalam pergaulan dan interaksi sosial di sekolah melalui pemahaman, penghayatan dan pengamalan etika, tata krama, norma dan aturan lainnya yang berlaku di sekolah. Salah satu bentuk kegiatan pembinaan kedua kompetensi ini ialah melalui pengajian yang diisi oleh Pimpinan Cabang Muhammadiyah Gunung Terang dan arisan guru dan karyawan satu bulan sekali .Pembinaan kompetensi profesional akan dilakukan melalui program pendidikan dan latihan baik dalam bentuk workshop,. In hose training (IHT), seminar, focus group discusion (FGD) dan kompetisi guru berprestasi.

Seperti halnya SDIT Muhammadiyah Gunung Terang, perencanaan pembinaan tenaga pendidik (guru) dilingkungan SDIT Permata Bunda III terdiri atas 1. Rekrutmen, 2. Diklat, 3. Pemberian reward, dan 4. Evaluasi. Proses rekrutmen calon guru deawali dengan pembentukan panitia rekrutmen yang sepenuhnya berasal dari yayasan Darul Hikmah. Materi seleksi terdiri atas seleksi berkas, tes potensi akademik, Hafalan Al-qur,an, psiko test, wawancara, micro teaching. Selanjutnya calon guru diwajibkan mengikuti kegiatan magang selama dua pekan dari pagi hingga sore hari. Tahap seleksi paling akhir adalah pengumuman akhir.

Para guru yang telah dinyatakan diterima, selanjutnya akan diberikan beberapa bentuk pelatihan. Pertama, pelatihan selama tiga hari dengan materi meliputi ; JSIT (Jaringan Sekolah Islam terpadu) an, kurikulum, kesiswaan, persiapan mengajar, dan tentang Yayasan Darul Hikmah. Kedua, Pelatihan penguatan kapasitas guru. Kegiatan ini biasanya dalam bentuk pembinaan baik oleh pihak eksternal atau pihak yayasan. Kegiatan berikutnya adalah raker guru dan yang terakhir adalah kegiatan persiapan pengenalan sekolah tahun ajaran baru. Ketiga, Pada hari Sabtu pekan I para guru akan mengikuti kegiatan KKG yang diikuti 
seluruh unit. Materi utama pada kegiatan ini adalah pembuatan bahan ajar yang terintegrasi dengan nilai-nilai Islam. Pada pekan kedua, rapat sekolah perunit. Materi utama pada rapat ini adalah membahas budaya sekolah. Pekan ke tiga dan ke empat mengikuti pelatihan dengan materi disesuaikan dengan kebutuhan prioritas. Seperti tentang Kurikulum 13 yang direvisi dan penilaian hasil belajar.

Langkah perencanaan pembinaan guru berikutnya adalah memberikan reward kepada guru yang berprestasi berupa beasiswa melanjutkan studi sebanyak tiga orang guru pertahun dan memberikan kesempatan menunaikan Umroh kepada dua orang pertahun. Langkah perencanaan pembinaan yang terakhir adalah melakukan evaluasi kinerja melalui Uji Kompetensi Guru yang dilakukan per semester dengan materi pokok empat kompetensi guru (padagogik, kepribadian, sosial dan profesional) ditambah kompetensi spiritual.

\section{Pelaksanaan Pembinaan Tenaga Pendidik (Guru) SDIT Muhammadiyah Gunung Terang dan SDIT Permata Bunda III Sukabumi}

Tahap pertama pembinaan tenaga pendidik (guru) dimulai sejak proses rekrutmen. Yaitu dengan cara mengkonstruksi persyaratan seleksi sedemikian rupa sehingga melalui instrumen-instrumen tes yang dibuat diharapkan akan terjaring para guru yang berkualitas. Sebagian tahapan seleksi dilaksanakan di sekolah mulai dari tahap pemberkasan, tes kemampuan dasar, tes mengajar (micro teaching), Sedangkan wawancara dilakukan oleh Pimpinan Cabang Muhammadiyah Gunung Terang. Calon yang dinyatakan lolos seleksi tahap awal selanjutnya diwajibkan mengikuti kegiatan magang selama 6 bulan sebagai masa percobaan. Selama magang yang bersangkutan diberi gaji sebesar Rp. 750.000,00 dan setelah berstatus guru tetap maka gajinya dibayar penuh dengan standar awal sebesar Rp. 1,3 Juta. Prestasi/kinerja calon guru selama aktivitas magang seperti kemampuan mengajar, sikap dalam pembelajaran, akhlak dan kedisiplinan akan menentukan status calon guru tersebut selanjutnya. Bagi yang dinyatakan berkinerja baik maka yang bersangkutan diusulkan oleh kepala sekolah ke Majelis Dikdasmen PCM Gunung Terang untuk ditetapkan sebagai guru tetap dilingkungan SDIT Muhammadiyah Gunung Terang melalui Surat Keputusan (SK). 
Tahap pembinaan kedua adalah mengikuti kegiatan rutin mingguan setiap hari jum'at berupa workshop yang dipandu oleh Kepala Sekolah dan Tim Manajemen Sekolah. Dalam kegiatan tersebut para guru dibekali dengan materi seperti metode pembelajaran, media pembelajaran, bahan ajar dan hafalan al-qur'an. Tahap pembinaan ketiga berupa pencerahan dan penguatan spiritual dalam bentuk pengajian umum dan diskusi tentang ke Islaman dan ke-Muhammadiyahan.Semua guru diwajibkan untuk mengikuti kegiatan tersebut. Pembinaan tahap keempat adalah Gerakan Tilawah Al-Qur'an (GTA). Kegiatan ini bersifat harian artinya setiap guru wajib untuk melaksanakan gerakan membaca Al-Qur'an setiap hari. Pada kegiatan ini para guru dibagi dalam tiga kategori. 1. Guru yang mampu membaca dua lembar perhari 2. Guru yang mampu membaca setengah juz perhari dan yang ke 3. Guru yang mampu membaca 1 juz perhari. Bagi guru yang lebih dari tiga kali tidak melaporkan progres/kemajuan membaca pada levelnya masing-masing maka kepala sekolah berhak untuk memindahkan dalam kelompok atau level yang berbeda. Pembinaan tahap kelima dilakukan dalam bentuk kegiatan workshop. Materi yang disajikan terdiri atas dua macam. Pertama terkait dengan sistem dan pola komunikasi para guru dengan orang tua, siswa dan teman sejawat. Sarana komunikasi dengan orang tua dibuat dalam bentuk grup WhatsApp (WA) dan buku penghubung. Kedua, pelatihan tentang pembuatan perangkat pembelajaran, media pembelajaran dan bahan ajar.

Seperti halnya SDIT Muhammadiyah Gunung Terang, pembinaan tenaga pendidik (guru) dilingkungan SDIT Permata Bunda III dilaksanakan dalamm empat kegiatan utama yaitu : 1. Rekrutmen, 2. Diklat, 3. Pemberian reward, dan 4. Evaluasi. Proses rekrutmen calon guru deawali dengan pembentukan panitia rekrutmen yang sepenuhnya berasal dari yayasan Darul Hikmah. Materi seleksi terdiri atas seleksi berkas, tes potensi akademik, Hafalan Al-qur,an, psiko test, wawancara, micro teaching. Selanjutnya calon guru diwajibkan mengikuti kegiatan magang selama dua pekan dari pagi hingga sore hari. Tahap seleksi paling akhir adalah pengumuman akhir.

Para guru yang telah dinyatakan diterima, selanjutnya diberikan beberapa bentuk pelatihan. Pertama, pelatihan selama tiga hari dengan materi meliputi ; JSIT (Jaringan Sekolah Islam terpadu) - 
an, kurikulum, kesiswaan, persiapan mengajar, dan tentang Yayasan Darul Hikmah. Kedua, Pelatihan penguatan kapasitas guru. Kegiatan ini dalam bentuk pembinaan baik oleh pihak eksternal atau pihak yayasan. Kegiatan berikutnya adalah raker guru dan yang terakhir adalah kegiatan persiapan pengenalan sekolah tahun ajaran baru. Ketiga, Pada hari Sabtu pekan I para guru mengikuti kegiatan KKG yang diikuti seluruh unit. Materi utama pada kegiatan ini adalah pembuatan bahan ajar yang terintegrasi dengan nilai-nilai Islam. Pada pekan kedua, rapat sekolah perunit. Materi utama pada rapat ini adalah membahas budaya sekolah. Pekan ke tiga dan ke empat mengikuti pelatihan dengan materi disesuaikan dengan kebutuhan prioritas. Seperti tentang Kurikulum 13 yang direvisi dan penilaian hasil belajar.

\section{E. Evaluasi Kegiatan Tenaga Pendidik (Guru) SDIT Muhammadiyah Gunung Terang dan SDIT Permata Bunda III Sukabumi}

Kegiatan manajerial yang ketiga dalam rangka pembinaan kinerja guru adalah dengan melakukan evaluasi baik perkegiatan dan harian, maupun secara komprehensif- integralistik melalui Uji Kompetensi Guruyang dilakukan persemester dengan materi pokok empat kompetensi guru (padagogik, kepribadian, sosial dan profesional) ditambah kompetensi spiritual. Guru yang memiliki hasil evaluasi baik (memiliki kinerja yang baik) diberikan reward (penghargaan). Penghargaan diberikan dalam beberapa bentuk. Pertama, dalam bentuk pujian lisan maupun dengan mempublish prestasi dalam bentuk banner di lingkungan sekolah. Kedua, memberikan penghargaan dalam bentuk sertifikat/piagam. Ketiga, mfasilitasi kegiatan guru, Keempat, memberi penghargaan dalam bentuk uang disetiap kegiatan yang dialokasikan antara lain dari dana BOS. Kelima, Setiap hari guru nasional dilakukan pemilihan guru berprestasi ditingkat sekolah. Bagi yang berhasil sebagai pemenang diberikan hadiah berupa uang dan sertifikat. Keenam, memberikan beasiswa melanjutkan studi untuk tiga orang guru pertahun dengan bantuan sebesar 13,5 juta perorang serta memberangkatkan ibadah umroh untuk4-5 orang guru pertahun. Ketujuh, Menyediakan pinjaman uang melalui PCM Gunung Terang dan koperasi sekolah maksimal pinjaman sebesar Rp. 5 Juta. Selain ketujuh bentuk penghargaan tersebut, setiap tahun ajaran baru sekolah memberikan bantuan bahan 
pakaian seragam sekolah berikut ongkos jahit diluar bantuan bahan seragam yang diberikan oleh Wali Kota Bandar Lampung. Sebagai bentuk penghargaan dan pelayanan prima di sekolah ini, maka setiap hari para guru dan karyawan mendapat jatah makan siang. Sedangkan untuk jatah makan siang hari senin dan kamis diganti uang dan dibayarkan bersama gaji bulanan karena pada dua hari tersebut para guru dan karyawan melaksanakan puasa sunnah senin-kamis. Dalam rangka membangun dan mempertebal sikap sosial, di sekolah ini juga menyediakan bantuan sosial baik untuk kategori kegiatan suka cita maupun sakit atau musibah lainnya.

Selain memberikan reward, kepala sekolah juga menerapkan punishmant dalam rangka pembinaan. Teguran diberikan kepada guru yang melanggar kedisiplinan dalam menjalankan tugas di sekolah. Semua guru diwajibkan masuk pada pukul 07.15 WIB. dan telah standby di depan Finger Print pada pukul 07.05 WIB. Tingkat kehadiran para guru yang terekam dalam mesin finger print tersebut setiap bulan di print dan diumumkan (ditempel) di dinding pengumuman sekolah sebagai bentuk pertanggung jawaban. Pengumuman tingkat kehadiran tersebut telah diurutkan sesuai ranking kehadiran dan ditanda tangani oleh guru yang bersangkutan.

Seperti halnya di SDIT Muhammadiyah Gunung Terang, evaluasi dalam rangka pembinaan guru dilaksanakan dalam dua bentuk. Pertama, evaluasi yang dilaksanakan dalam kegiatan dan kedua, evaluasi yang dilaksanakan secara terpadu dalam waktu yang telah ditentukan (kalender sekolah). Untuk evaluasi terpadu dilaksanakan dalam tiga bentuk kegiatan yaitu Uji Kompetensi Guru, Supervisi Kepala Sekolah, dan Penilaian tim sejawat. Hasil evaluasi dituangkan dalam bentuk raport guru. Bagi guru yang memiliki nilai raport baik maka Yayasan dan Sekolah memberikan reward dalam bentuk :

1. Beasiswa untuk melanjutkan pendidikan yang lebih tinggi ( S2). Beasiswa ini diberikan kepada 3 orang guru pertahun. Selain prestasi dan kinerja dalam pembelajaran, lama pengabdian / mengajar juga menjadi salah satu kriteria dalam penentuan beasiswa.

2. Menunaikan ibadah umroh untuk 2 orang pertahun. 
3. Memberikan hadiah uang sebesar Rp. 50.000,-perorang bagi guru yang disiplin dalam kehadiran. Akumulasi kehadiran berdasarkan finger print ditempel didinding sekolah.

4. Nilai raport guru berimbas pada pemberian besaran gaji dan tunjangan kinerja (Tukin) guru yang diberikan oleh pihakYayasan Darul Hikmah.

5. Tunjangan transportasi. Setiap guru yang hadir di sekolah diberi tunjangan transportasi sebesar Rp. 15.000,- per hari. Jika guru dapat hadir tepat waktu sesuai jam masuk yang telah ditentukan (pukul 07.00 WIB.) pagi, maka tunjangan transportasinya ditambah Rp. 5000,- sehingga menjadi Rp. 20.000,--

6. Setiap awal tahun pelajaran semua guru dan karyawan diberi bantuan bahan seragam mengajar yang diberikan oleh pihak yayasan berikut ongkos jahit.

\section{F. Pembentukan Karakter Bangsa Yang Pancasilais Pada SDIT Muhammadiyah Gunung Terang dan SDIT Permata Bunda III Sukabumi}

Dalam upaya pembinaan mutu guru, baik SDIT Muhammadiyah Gunung Terang maupun SDIT Permata Bunda III Sukabumi sama-sama telah menerapkan langkah pembinaan yang moderen yaitu dengan mengimplementasikan tiga fungsi manajemen yaitu perencanaan (planning), pelaksanaan (actuating), dan evaluasi (controlling). Pada tahap perencanaan dimulai dengan rekrutmen guru dengan prioritas mutu yang diinginkan. Rekrutmen ini berdimensi jangka panjang. Perencanaan diklat dalam berbagai bentuk dalam upaya meningkatkan mutu guru berdimensi jangka menengah. Perencanaan ketiga adalah evaluasi yang dilaksanakan secara berjenjang, harian, bulanan, tengah semester, satu semester dan satu tahun pelajaran.Produk dari evaluasi adalah nilai kinerja guru yang kemudian dijadikan dasar dalam memberikan penghargaan dan teguran. Tahap pelaksanaan diprioritaskan pada upaya pembinaan kompetensi dan pemberian motivasi untuk mengoptimalkan kinerja guru. Tahap evaluasi digunakan untuk melihat tingkat singkronisasi antara perencanaan dan implementasi di lapangan. Evaluasi juga digunakan untuk mengetahui tingkat kemajuan kinerja guru sekaligus untuk memberikan reward dan punishment. 
Ketiga fungsi sekaligus langkah manajemen tersebut dilaksanakan secara terintegratif dan berkesinambungan. Langkah tersebut sejalan dengan upaya peningkatan mutu guru yang kemukakan oleh Yamin Martinis danMaisah ${ }^{15}$, meliputi : 1 . Perencanaan strategis bertujuan untuk memberi pedoman dan arahan bagi sekolah dalam rangka mencapai visi dan misi yang telah ditetapkan. 2. Pengembangan program strategis menyangkut pengadaan, penggunaan dan pengaturan sumber-sumber untuk keberlangsungan suatu program kegiatan. 3. Melakukan pengawasan dan evaluasi untuk memastikan singkronisasi antara perencanaan dan pelaksanaan baik pada level individual maupun institusional. Evaluasi dilaksanakan dalam tiga jenjang. Evaluasi harian, untuk melihat secara langsung kemajuan peserta didik oleh guru. Evaluasi ini berlangsung secara informal. Kedua jangka pendek.Bersifat spesifik dan terstruktur bertujuan memastikan bahwa peserta didik sudah berada pada jalur yang seharusnya dalam mengoptimalkan potensi dan meraih prestasi. Ketiga, evaluasi jangka panjang untuk melihat kemajuan kinerja dalam skala yang lebih komprehensif.

Dalam konteks manajemen mutu sekolah, perencanaan yang dibuat oleh kedua SDIT tersebut memegang peranan yang sangat penting dan strategis untuk mempersiapkan dan meraih kemajuan prestasi pendidikan di sekolah. Karena perencanaan merupakan fungsi pertama dalam manajemen dan menjadi faktor penting dalam meningkatkan kualitas manajerial dalam suatu lembaga pendidikan. Perencanaan yang baik akan menjadi landasan yang kuat bagi implementasi fungsi-fungsi yang lain berikutnya. Sondang P. Siagian dalam Ramayulis dan Mulyadi ${ }^{16}$ menyatakan bahwa perencanaan adalah kegiatan awal dalam pelaksanaan manajemen. Perencanaan akan menentukan efektifitas dan efisiensi suatu kegiatan.Perencanaan didefinisikan sebagai keseluruhan proses pemikiran dan penentuan secara matang dari hal-hal yang akan dikerjakan dimasa yang akan datang dalam rangka mencapai tujuan.

\footnotetext{
${ }^{15}$ Yamin Martinis danMaisah, ,StandarisasiKinerja Guru (Jakarta: GaungPersada Press, 2010). h. 35.

${ }^{16}$ Ramayulis Mulyadi, Manajemen E Kepemimpinan Pendidikan Islam (Jakarta: Kalam Mulia, 2017). h. 55.
} 
Dilihat dari perencanaan yang dibuat kedua sekolah dalam rangka melakukan pembinaan mutu guru nampak bahwa kedua sekolah menyiapkan seperangkat instrumen yang mampu menjawab kebutuhan pendidikan masa kini dan masa yang akan datang. Kedua sekolah bukan saja membutuhkan guru yang profesional dalam empat kompetensi (paedagogik, sosial, kepribadian dan profesional) tetapi juga menguasai kompetensi kelima yaitu kompetensi spiritual. Guru harus mampu menjadi teladan /"uswatun khasanah" Bukan saja dalam dimensi intelektual melainkan juga dalam akhlak dan prilakunya. Dengan kata lain guru dituntut untuk berilmu amaliah dan beramal ilmiah. Standar rujukan nya adalah ajaran Islam yang tertuang dalam Al-Qur'an dan Al-Hadist. Untuk menghasilkan out put pendidikan yang demikian diperlukan pendidik yang berdimensi "duniawi dan ukhrowi". Kedua sekolah meyakini dibawah bimbingan guru yang cerdas intelektualnya, ikhlas dan bersih hatinya serta mulia akhlak dan perbuatannya akan mampu melahirkan generasi yang berkualitas.Guru yang demikian harus disiapkan sejak awal melalui proses rekrutmen yang sesuai dengan visi dan misi yang ingin dicapai.

Selanjutnya, pada tataran pengembangan karakter siswa menjadi bangsa yang pancasilais, Pancasila merupakan philosofische grondslag yaitu pondasi ${ }^{17}$, falsafah, pikiran, jiwa, dan hasrat yang sedalam-dalamnya sebagai dasar didirikannya bangunan Indonesia merdeka yang kekal dan abadi. Pancasila menjadi dasar statis yang mempersatukan dan bintang penuntun (leitstar) yang dinamis untuk mengarahkan bangsa ini mencapai tujuannya. Maka, nyatalah bahwa Pancasila merupakan landasan hidup bernegara (dasar negara) sekaligus ideologi nasional yang ideal. Untuk menghasilkan out put pendidikan yang demikian diperlukan pendidik yang berKarakter sesuai dan ditunjukkan sikap yang berkaitan dengan nilai-nilai yang terkandung dalam Pancasila, yaitu nilai karakter yang religius, peduli sosial, kemandirian, semangat kebangsaan, demokratis, toleransi, dan disiplin. Kedua sekolah meyakini dibawah bimbingan guru yang berkarakter pancasilais akan mampu melahirkan generasi yang berkualitas.Guru yang demikian harus disiapkan sejak awal melalui proses rekrutmen yang sesuai dengan visi dan misi yang ingin dicapai. Tujuan manajemen pendidik dengan pendidikan karakter pancasila yaitu

${ }^{17}$ Oleh Hendra Kurniawan, “Mewujudkan Masyarakat Pancasilais," t.t., 3. 
memfasilitasi siswa agar mampu menggunakan pengetahuan; mengkaji, menginternalisasi, dan mempersonalisasikan nilai; serta mengembangkan keterampilan sosial

dan akhlak mulia dalam diri siswa, sehingga dapat mewujudkannya dalamperilaku sehari-hari dalam berbagai konteks sosial budaya yang berbhineka sepanjang hayat. ${ }^{18}$

Pada tataran pelaksanaan berbagai program pembinaan guru di kedua sekolah lebih dititik beratkan pada pembinaan kompetensi. Bukan saja empat kompetensi guru yang secara umum tertuang dalam Permendiknas RI Nomor 16 Tahun 2007, bahkan ditambah satu kompetensi lagi yaitu kompetensi spiritual.Hal inilah yang membedakan kedua SDIT dengan Sekolah Dasar umum lainnya. Selain pembinaan kompetensi, maka pembinaan motivasi serta upaya mengarahkan para guru untuk bekerja secara optimal menjadi nilai tambah tersendiri bagi kedua sekolah.Membangun motivasi sangat diperlukan karena kinerja akan sangat bergantung pada seberapa tinggi motivasi seseorang dalam bekerja. Motivasi kerja berhubungan erat dengan prilaku dan prestasi kerja. Semakin tinggi motivasi seseorang dalam melakukan suatu pekerjaan maka akan semakin baik pula prilakunya dalam bekerja sehingga memberi peluang berprestasi yang lebih baik ${ }^{19}$.Dalam rangka membangun motivasi guru berbagai upaya dilakukan kedua sekolah. Mulai dari memberikan reward berupa beasiswa melanjutkan studi ke jenjang S2 hingga memberi kesempatan menunaikan ibadah umroh bagi guru-guru yang berkinerja tinggi. Pembinaan motivasi di kedua sekolah secara umum lebih banyak dilakukan oleh kepala sekolah dan pihak Yayasan sebagai leader sekaligus manager. Hal ini sejalan dengan prinsip seorang manajer yang dikemukakan olehStephen P. Robbins dan Mary Coulter ${ }^{20}$ yang menyatakan bahwa tugas seorang manajer adalah mengkoordinasikan dan mengawasi pekerjaan orang lain sehingga tujuan yang diharapkan dapat tercapai. Seorang manajer tidak bekerja

18 Widya Noventari, "HARMONISASI NILAI-NILAI PANCASILA DALAM SISTEM AMONG SESUAI DENGAN ALAM PEMIKIRAN PENDIDIKAN KI HAJAR DEWANTARA," Jurnal Pancasila dan Kewarganegaraan 1, no. 1 (2016): 10.

${ }^{19}$ Hamzah B Uno, TeoriMotivasidanPengukurannya : Analisis di BidangPendidikan (Jakarta: BumiAksara, 2007).h. 67.

20 Stephen P. Robbins, Mary Coulter, Management (Eleventh Edition), (One LakeStreet, Upper Saddle River, New Jersey 07458: publishing as Prentice Hall Pearson Education, Inc., 2012). 
untuk dirinya sendiri tetapi membantu orang lain melakukan pekerjaan merekaseseorang yang berkoordinasi dan mengawasi pekerjaan orang lain sehingga tujuan organisasi dapat tercapai.

Kegiatan evaluasi dikedua SDIT dilaksanakan dengan tujuan untuk melihat seberapa baik kinerja guru dalam melaksanakan tugas pembelajaran di sekolah. Secara umum Evaluasi dilaksanakan dalam bentuk Uji Kompetensi Guru. Hasil yang dicapai diberikan dalam bentuk raport guru persemester. Selain dengan UKG, evaluasi juga dilakukan dalam proses supervisi kepala sekolah dan teman sejawat. Evaluasi juga dimaksudkan untuk melihat singkronisasi dan konsistensi antara perencanaan dan pelaksanaan program pembinaan mutu guru yang telah dibuat. Selain kedua hal tersebut evaluasi juga dimaksudkan sebagai metode dalam menegakkan kedisiplinan dalam menjalankan tugas. Guru-guru yang tidak disiplin dalam menjalankan tugas diberikan teguran baik lisan maupun tertulis. Hasil evaluasi digunakan sebagai upaya perbaikan/peningkatan program yang sama atau yang serupa dimasa datang. Suatu program yang tidak dievaluasi, maka tidak akan dapat diketahui bagaimana dan seberapa tinggi kebijakan yang sudah diambil dapat terlaksana. Informasi hasil evaluasi sangat sangat berguna bagi pengambilan keputusan dan kebijakan program berikutnya ${ }^{21}$. Hasil evaluasi dapat digunakan sebagai dasar dalam membuat rekomendasi apakah suatu kegiatan atau program akan dilanjutkan, diperbaiki/ direvisi, disosialisasikan atau justru dihentikan karena tidak sesuai dengan tujuan yang

\section{G. Simpulan}

Berdasarkan hasil penelitian ini dapat disimpulkan hal-hal sebagai berikut : SDIT Muhammadiyah Gunung Terang dan SDIT Permata Bunda III Suka Bumi Bandar Lampung adalah sekolah yang memiliki paradigma mutu. Hal ini dibuktikan dengan melakukan pembinaan tenaga pendidik (guru) berbasis pola pembinaan yang maju, moderen dan berdaya saing yaitu dengan menggunakan langkah-langkah manajemen pendidikan.

\footnotetext{
${ }^{21}$ SuharsimiArikuntoCepiSafruddin Abdul Jabar, Evaluasi Program Pendidikan: PedomanTeoritisPraktisBagiMahasiswadanOraktisiPendidikan ,EdisiKedua (Jakarta: BumiAksara, t.t.).h. 22.
} 
Pembinaan guru dilakukan secara sistematis melalui tiga tahapan manajemen yaitu perencanaan, pelaksanaan dan evaluasi.

1. Pada tahap perencanaan, diawali dengan proses rekrutmen calon guru dengan mengkonstruksi instrumen seleksi yang dapat menghasilkan gurus yang berkualitas baik intelektual, emosional, sosial dan spiritual. Selanjutnya merancang kegiatan pembinaan kompetensi guru yang meliputi lima kompetensi: kompetensi paedagogik, kompetensi kepribadian, kompetensi sosial, kompetensi profesional, kompetensi spiritual dan pancasilais.

2. Pada tahap pelaksanaan, pembinaan tenaga pendidik dikonsentrasikan pada upaya peningkatan kompetensi (5 kompetensi utama), pembinaan motivasi kerja dan pemberian reward atas kinerja/ prestasi kerja yang dicapai. Berbagai kegiatan akademik dan non akademik disiapkan oleh sekolah agar para guru menjadi pendidik yang unggul, berprestasi dan mampu menjadi teladan pendidikan di sekolah. Pemberian beasiswa melanjutkan studi S2, bantuan ibadah umroh, pemilihan guru berprestasi, kesempatan menghafal Al-Qur'an dalam beberapa tingkatan, perbaikan kesejahteraan berbasis kinerja, merupakan program unggulan kedua sekolah dalam rangka pembinaan mutu guru.

3. Pada tahap Evaluasi, Para guru diwajibkan untuk mengikuti Uji Kompetensi Guru (UKG), supervisi, dan evaluasi oleh teman sejawat. Hasil evaluasi digunakan sebagai dasar dalam mengambil kebijakan pembinaan berikutnya[.]

\section{REFERENSI}

Cepi Safruddin Abdul Jabar, Suharsimi Arikunto. Evaluasi Program Pendidikan: Pedoman Teoritis Praktis Bagi Mahasiswa dan Oraktisi Pendidikan, Edisi Kedua. Jakarta: Bumi Aksara, 2010.

Kadarisman, Yoskar, dan Ary Saputra. "Motivasi Orang Tua Menyekolahkan Anak ke Sekolah Islam Terpadu (Studi pada Sdital-madinah Kota Pekanbaru)." Jurnal Online Mahasiswa Fakultas Ilmu Sosial dan Ilmu Politik Universitas Riau 2, no. 2 (2015). 
Kurniawan, Oleh Hendra. "Mewujudkan Masyarakat Pancasilais," t.t., 3.

Martinis, Yamin dan Maisah. , Standarisasi Kinerja Guru. Jakarta: Gaung Persada Press, 2010.

Miles, Matthew B. dan A. Michael Huberman. Analisis Data Kualitatif. Jakarta: UI -Press, 1992.

Moleong, Lexy J. Metodologi Penelitian Kualitatif. Bandung: PT Remaja Rosdakarya, 2000.

- - . Metodologi Penelitian Kualitatif. Bandung: Remaja Rosdakarya, 2008.

Mulyadi, Ramayulis. Manajemen E Kepemimpinan Pendidikan Islam, 2017.

Noor, Fu'ad Arif. "MANAJEMEN GURU RAUDLATUL ATHFAL (RA) DALAM TOTAL QUALITY MANAGEMENT (TQM)." Jurnal Pendidikan Islam 3, no. 1 (2015): 21.

Noventari, Widya. “HARMONISASI NILAI-NILAI PANCASILA DALAM SISTEM AMONG SESUAI DENGAN ALAM PEMIKIRAN PENDIDIKAN KI HAJAR DEWANTARA." Jurnal Pancasila dan Kewarganegaraan 1, no. 1 (2016): 10.

Rahman, Arif. "Paradigma Kritis Pancasila dalam Dimensi Pendidikan Islam" 10, no. 1 (2015): 20.

Stephen P. Robbins, Mary Coulter,. Management (Eleventh Edition),. One LakeStreet, Upper Saddle River, New Jersey 07458: publishing as Prentice Hall Pearson Education, Inc., 2012.

Sudarman, Danim. Menjadi Peneliti Kualitatif Rancangan Metodologi, Presentasi, dan Publikasi Hasil Penelitianuntuk Mahasiswa dan Penelitian Pemula Bidang Ilmu Sosial, Pendidikan, dan Humaniora. Bandung: Remaja Rosdakarya, 2002.

Sugiyono. Metode Penelitian Kombinasi. Bandung: Alfa Beta, 2012.

- - - Metode Penelitian Kuantitatif, Kualitatif Dan RED. Bandung: CV. Alfabeta, t.t.

Sulaiman, Deded. "MANAJEMEN PENDIDIKAN PESANTREN MODERN DALAM PEMBENTUKAN KARAKTER ANAK:," t.t., 8 . 
Uno, Hamzah B. Teori Motivasi dan Pengukurannya: Analisis di Bidang Pendidikan. Jakarta: Bumi Aksara, 2007.

Yin Robert, K. Studi kasus ( Desain dan Metode). Jakarta: Raja GrafindoPersada, 2011. 